\title{
The wheat Sr22, Sr33, Sr35 and Sr45 genes confer resistance against stem rust in barley
}

M. Asyraf Md. Hatta ${ }^{1,2}$, Ryan Johnson ${ }^{3}$, Oadi Matny ${ }^{3}$, Mark A. Smedley ${ }^{1}$, Guotai $\mathrm{Yu}^{1}$, Soma Chakraborty ${ }^{4}$, Dhara Bhatt ${ }^{4}$, Xiaodi Xia ${ }^{4}$, Sanu Arora ${ }^{1}$, Burkhard Steuernagel ${ }^{1}$, Terese Richardson ${ }^{4}$, Rohit Mago ${ }^{4}$, Evans S. Lagudah ${ }^{4}$, Nicola Patron ${ }^{5}$, Mick Ayliffe ${ }^{4}$, Matthew N. Rouse ${ }^{6,3}$, Wendy A. Harwood $^{1}$, Sambasivam K. Periyannan ${ }^{4}$, Brian J. Steffenson ${ }^{3}$, Brande B. H. Wulff ${ }^{1}$

${ }^{1}$ John Innes Centre, Norwich Research Park, Norwich, NR4 7UH, United Kingdom

${ }^{2}$ Department of Agriculture Technology, Faculty of Agriculture, Universiti Putra Malaysia, Serdang, Malaysia

${ }^{3}$ Department of Plant Pathology, Stakman Borlaug Center for Sustainable Plant Health, University of Minnesota, St. Paul, MN 55108, USA

${ }^{4}$ Commonwealth Scientific and Industrial Research Organization (CSIRO), Agriculture and Food, General Post Office Box 1700, Canberra, ACT 2601, Australia

${ }^{5}$ The Earlham Institute, Norwich Research Park, Norwich NR4 7UZ, United Kingdom

${ }^{6}$ USDA-ARS Cereal Disease Laboratory, St. Paul, MN 55108, USA

Correspondence email: brande.wulff@jic.ac.uk; bsteffenson@umn.edu; and sambasivam.periyannan@csiro.au

Keywords: Ug99, stem rust, wheat, barley, Sr22, Sr33, Sr35, Sr45, stacking, durable disease resistance.

Word count $(\max 7000)$

Summary: 190

Introduction: 1615

Results: 1084

Discussion: 1308

Experimental procedures: 1141

Acknowledgements: 55

Author contributions: 100

Table titles: 0

Figure legends: 390

Total: 5883 


\section{Summary}

In the last 20 years, stem rust caused by the fungus Puccinia graminis f. sp. tritici (Pgt), has reemerged as a major threat to wheat and barley cultivation in Africa and Europe. In contrast to wheat with 82 designated stem rust $(S r)$ resistance genes, barley's genetic variation for stem rust resistance is very narrow with only seven resistance genes genetically identified. Of these, only one locus consisting of two genes is effective against Ug99, a strain of Pgt which emerged in Uganda in 1999 and has since spread to much of East Africa and parts of the Middle East. The objective of this study was to assess the functionality, in barley, of cloned wheat $\mathrm{Sr}$ genes effective against Ug99. Sr22, Sr33, Sr35 and Sr45 were transformed into barley cv. Golden Promise using Agrobacterium-mediated transformation. All four genes were found to confer effective stem rust resistance. The barley transgenics remained susceptible to the barley leaf rust pathogen Puccinia hordei, indicating that the resistance conferred by these wheat $\mathrm{Sr}$ genes was specific for Pgt. Cloned Sr genes from wheat are therefore a potential source of resistance against wheat stem rust in barley.

\section{Introduction}

Stem rust, caused by the fungus $P$. graminis f. sp. tritici $(P g t)$, is one of the major threats to barley (Hordeum vulgare) production in North America (Steffenson, 1992) and Australia (Dill-Macky et al., 1991). This destructive fungal disease can cause a significant reduction in plant growth and yield of both barley and wheat (De Wolf et al., 2011). In 1999, a new virulent isolate of Pgt called Ug99 (typed as race TTKSK according to Jin et al., 2008) was detected in Uganda which had overcome Sr31, a widely deployed stem rust resistance gene in bread wheat (Triticum aestivum) (Pretorius et al., 2000). At that time Ug99 and its derivatives were virulent on more than $80 \%$ of the world's wheat cultivars (Singh et al., 2008). In recent years new Pgt races, that are not members of the Ug99 race group, have caused disease outbreaks on wheat in Europe (including Germany (Olivera Firpo et al., 2017), and Italy (Bhattacharya, 2017)), Asia (Russia (Shamanin et al., 2016)), and Africa (Ethiopia (Olivera et al., 2015)).

Effective ways of controlling this disease include fungicide application and breeding for resistant cultivars (Mclntosh et al., 1995), with this latter strategy being the most cost effective and environmentally acceptable. However, when lines carrying a single resistance $(R)$ gene effective against a specific disease are deployed, strong selection pressure is imposed on the pathogen population usually leading to resistance breaking down and the potential outbreak of an epidemic (Stakman, 1957). Notwithstanding, there are a few cases where $R$ genes effective against Pgt have shown remarkable durability despite being deployed as a single gene for many years over a wide area where the pathogen is prevalent. Examples of such durability include Sr31 which protected wheat from major losses for over 30 years until the Ug99 outbreak in 1999 (Ayliffe et al., 2008; Pretorius et al., 2000; Singh et al., 2006) and barley Rpg1, which has been widely deployed since the 1940s (Brueggeman et al., 2002). An alternative strategy is the simultaneous deployment of several $R$ genes within a cultivar to prolong $R$ gene efficacy in the field. There is no selective advantage for pathogen strains that have mutated to overcome a single $R$ gene in the cultivar, thus imposing a barrier to the stepwise evolution of virulence (Dangl et al., 2013; Ellis et al., 2014; McDonald and 
Linde, 2002). However, it is difficult to ensure that multiple $R$ genes, which may be scattered throughout the genome, remain together in a breeding program.

None-the-less, genetic resistance to cereal rust diseases has been fundamental for crop protection. For more than 100 years, breeders have introgressed resistance into wheat by undertaking wide crosses between wheat and its wild or domesticated relatives. Notable examples include the transfer of the stem rust resistance genes Sr2 from emmer wheat (Triticum turgidum subsp. dicoccum) (McFadden, 1930), Sr31, Sr50 and Sr1RS ${ }^{A m i g o}$ from rye (Mago et al., 2005b), Sr24 and Sr26 from Thinopyrum ponticum (Mago et al., 2005a), and Sr36 from T. timopheevi (Mclntosh and Gyarfas, 1971). However, sexual incompatibility and long generation times can impose significant barriers to successful gene introgression (Erickson, 1945). Also, linkage drag of deleterious alleles has hindered the deployment of many Sr genes in wheat, i.e. Sr22 and Sr43 due to yellow flour pigmentation and/or reduced yield and delayed heading date (Knott, 1984; Marais, 1992; Niu et al., 2014).

In contrast to wheat, where 82 stem rust resistance genes have been described (McIntosh et al., 2017), only seven stem rust resistance genes have been reported in barley; these being Rpg1 (Brueggeman et al., 2002; Powers and Hines, 1933; Steffenson, 1992), Rpg2 (Case et al., 2018; Patterson et al., 1957), Rpg3 (Case et al., 2018; Jedel, 1990; Jedel et al., 1989), rpg4 (Jin et al., 1994), Rpg5 (Brueggeman et al., 2008; Sun and Steffenson, 2005; Sun et al., 1996), rpg6 (Fetch et al., 2009) and rpgBH (Steffenson et al., 1984; Sun and Steffenson, 2005). Rpg1 is the most widely deployed amongst these genes due to its broad-spectrum resistance which has remained effective for over 70 years (Brueggeman et al., 2002; Steffenson, 1992). However, a recent study showed that this gene is not effective to the Ug99 race TTKSK (Steffenson et al., 2017), leaving rpg4/Rpg5 as the only gene complex known to confer resistance to this Pgt race in barley (Steffenson et al., 2009). In addition, seedling assays undertaken on two panels of 1,924 and 934 genetically diverse barley cultivars and wild barley accessions (Hordeum vulgare subsp. spontaneum), showed that more than $95 \%$ and $97 \%$ of accessions respectively, were susceptible to race TTKSK. Hence, it is important to identify novel sources of resistance to safeguard barley from stem rust (Steffenson et al., 2017). Given the limited number of $R$ genes available for Pgt protection in barley, interspecies $R$ gene transfer is a potentially valuable alternative (Wulff and Moscou, 2014).

The majority of $R$ genes cloned encode proteins containing nucleotide-binding and leucine-rich repeat domains (NLR proteins) (Kourelis and van der Hoorn, 2018). Plant genomes typically contain several hundred NLR genes (Baggs et al., 2017). NLRs detect the presence of a pathogen by recognising pathogen effector molecules. This recognition can be direct, although more often it is indirect whereby the NLR (also known as the 'guard') recognises the effector-mediated modification of a host pathogenicity target, (also known as the 'guardee') (Dodds and Rathjen, 2010; Kourelis and van der Hoorn, 2018). NLR proteins that function by either mechanism have been successfully transferred by transgenesis to distantly related, nonsexually compatible species and shown to function in some instances. For example, the $L 6$ protein of flax (Linum usitatissimum, a member of the Linacea) directly binds a corresponding AvrL567 effector protein of the flax rust pathogen Melampsora lini. When the L6 gene is co-expressed with AvrL567 in Nicotiana benthamiana (a member of the Solanaceae) a 
hypersensitive resistance response is activated (Dodds et al., 2004). Similarly, a number of $R$ genes that function by guardee recognition have been shown to function upon interspecies transfer, exemplified by the transfer of the Arabidopsis thaliana (a Brassicaceae) guard and guardee gene pairs RPS2 or RPM1 with RIN4 (Day et al., 2005; Chung et al., 2011) and RPS5 with PBS1 (Ade et al., 2007) into $N$. benthamiana.

Transferring $R$ genes between species by conventional crossing can be a tedious task due to the extensive backcrossing usually required. However, it is now relatively straightforward to introduce these $R$ genes as transgenes by transformation thereby avoiding this breeding requirement. Further advantages of transgenesis include that transfer is not limited to sexually compatible species, there is no linkage drag, and it becomes possible to stack multiple $R$ genes at the same locus to ensure coinheritance. When transferred between different species and families these $R$ genes can function normally (reviewed in Wulff et al., 2011) and agronomically important examples include the Bs2 gene from pepper (Capsicum annuum) which was successfully transferred to tomato (Solanum lycopersicum), another Solanacous species, where it confers resistance to bacterial leaf spot (Tai et al., 1999) and CcRpp1 from pigeonpea (Cajanus cajan) which confers resistance to Asian soybean rust when introduced into soybean (Glycine max) (Kawashima et al., 2016).

Barley ( $H$. vulgare) and wheat ( $T$. aestivum) diverged from a common Triticeae ancestor approximately 10 to 14 million years ago (Schlegel, 2013) (Figure 1a). It is therefore likely that wheat NLR genes will function in barley, and that wheat Sr genes could be used to improve the resistance of barley to Pgt. Nine major, dominant Sr genes have been cloned so far from wheat or its wild progenitors; these being Sr13 from durum wheat (T. turgidum ssp. durum) (Zhang et al., 2017), Sr21, Sr22 and Sr35 from T. boeoticum and T. monococcum (Saintenac et al., 2013; Steuernagel et al., 2016, Chen et al., 2018), Sr33, Sr45, Sr46, and SrTA1662 from Aegilops tauschii (Periyannan et al., 2013; Steuernagel et al., 2016; Arora et al., 2018), and Sr50 from rye (Secale cereale) (Mago et al., 2015) (Figure 1b). All these genes encode coiled-coil (CC)-NLR proteins and confer resistance to the Ug99 race group.

In the coming years, it is anticipated that there will be a large increase in the number of cloned $\mathrm{Sr}$ genes due to the development of rapid $R$ gene isolation methods such as TACCA (Thind et al., 2017), MutRenSeq (Steuernagel et al., 2016), MutChromSeq (Sánchez-Martín et al., 2016), and AgRenSeq (Arora et al., 2018). Often the functional testing of $R$ gene candidates is delayed by the need to isolate native regulatory sequences and to assemble large binary constructs encoding the $R$ gene. This process can be accelerated by substituting regulatory elements from the previously cloned $R$ genes, and generating $R$ gene constructs using the type IIS restriction endonuclease-based Golden Gate cloning technique (Engler et al., 2008). Further, the incorporation of type IIS restriction sites allows the generation of user-defined overhangs thereby enabling simultaneous cloning of multiple fragments. This assembly method has dramatically decreased the amount of time required to design and develop gene constructs. However, one major requirement is that the fragments to be assembled must be free from recognition sites of the selected type IIS restriction endonuclease. This requires "sequence domestication" (removal of internal type IIS sites). While the open reading frame can be maintained 
due to the redundancy in the genetic code, the removal of sites from the regulatory sequences (introns, promoter and terminator) may affect gene expression and function.

In this study, we generated constructs encoding the wheat Sr22, Sr33, Sr35 and Sr45 genes using Golden Gate cloning and transformed these into barley (Figure 1b). The resultant transgenic barley lines showed high-levels of resistance to Pgt. Future stacking of these $\mathrm{Sr}$ genes might therefore be used to engineer more durable immunity towards wheat stem rust in barley (Figure 1c).

\section{Results}

The wheat Sr22, Sr33, Sr35, and Sr45 genes confer resistance against wheat stem rust in transgenic barley

To determine whether cloned wheat $S r$ genes can function in barley to confer wheat stem rust resistance, barley cultivar (cv.) Golden Promise was transformed with constructs encoding either Sr22 or Sr33 via Agrobacterium-mediated transformation. The Sr22 (9.8 kb) and Sr33 (7.9 kb) sequences encoded their respective native 5' and 3' regulatory sequences and were identical in sequence to the endogenous wheat genes (Figure 2a, 2b and Table S1). Single-copy, hemizygous, primary transgenics were identified amongst $T_{0}$ barley plants by Q-PCR so that single copy segregating $T_{1}$ or $\mathrm{T}_{2}$ families, or homozygous $\mathrm{T}_{2}$ lines could be tested in subsequent generations.

Eight progenies from ten Sr22 segregating $T_{1}$ families were inoculated with Pgt race MCCFC. Four families derived from lines 1370-11-01, 1370-17-01, 1370-19-01, 1372-08-01 segregated for resistance, while all the eight tested progenies from 1370-01-01 showed resistance (Figure 3a and Table S2). The resistant individuals in these families showed near immunity to this Pgt isolate (Figure 3a and Table S2) whereas susceptible segregants and Golden Promise control seedlings all showed extensive Pgt growth. The presence of the Sr22 transgene in resistant plants 1370-11-01 A, B, and C, and absence in susceptible sibling 1370-11-01-D and Golden Promise controls was confirmed by PCR amplification of the hptll selectable marker gene used for transformation (Figure S1a). In contrast, the barley endogenous CONSTANS gene was amplified from all samples indicating that the lack of amplification of $h p t / l$ from susceptible siblings and Golden Promise was not due to poor quality DNA (Figure S2a).

Four $T_{2}$ lines, each derived from an independent transgenic event, were selected that were homozygous for the Sr33 transgene and small $T_{3}$ families (11-12 seedlings) from each line inoculated with either Pgt race MCCFC or TKTTF. All seedlings tested showed resistance to both races of Pgt (Figure $3 b$ and $3 c$ and Table S3 and S4). In addition to susceptible Golden promise control seedlings, additional wheat control lines were included. The Sr33-containing cv. Chinese Spring and an EMS-derived mutant carrying a non-functional allele of Sr33 (Periyannan et al., 2013) were used as resistant and susceptible controls, respectively, to demonstrate the avirulence of Pgt race MCCFC to Sr33 (Table S3).

\section{Wheat NLR genes can be sequence-modified but retain gene function}


A functional wheat NLR transgene is typically $10 \mathrm{~kb}$ in length and consists of $4 \mathrm{~kb}$ of 5 ' and $3^{\prime}$ regulatory elements, $3 \mathrm{~kb}$ of exons and $3 \mathrm{~kb}$ of introns. These long, contiguous sequences can be difficult to isolate and verify from a non-reference hexaploid wheat genome, and their synthesis is expensive. Multi-segment Golden Gate assembly (Weber et al., 2011) was therefore tested as an alternative for rapid and cost-effective generation of full-length $\mathrm{Sr}$ gene constructs using either native or non-native regulatory sequences. Firstly, the effect of sequence domestication (i.e. the removal of all Type IIS Bsal and Bpil restriction enzyme sites) was examined on Sr33 function. Four Bpil sites were removed from the Sr33 promoter while $3 \mathrm{Bpil}$ and two Bsal sites were removed from the Sr33 open reading frame (Figure 2c). Although the Sr33 open reading frame was faithfully maintained through domestication, there was a risk that the removal of the four Bpil sites in the 5' regulatory sequence would disrupt gene function. The domesticated full-length Sr33 gene $\left(\mathrm{Sr}^{\mathrm{d}} \mathrm{3}^{\mathrm{d}}\right)$ was transformed into cv. Golden Promise and single-copy primary transgenics again selected by Q-PCR. $T_{1}$ progeny from 12 independent transgenic lines were infected with Pgt race MCCFC and nine $T_{1}$ families shown to segregate for resistance while the remaining three families were all susceptible (Figure 3d and Table S5). PCR analysis of the hptll selectable marker gene again confirmed the presence of the transgene in resistant plants and its absence in susceptible plants (Figure S1b), while the barley CONSTANS gene was amplified from all plant DNAs (Figure $\mathbf{S 2 b}$ ). These data confirm that $S r 33^{d}$ encodes functional Sr33 resistance in spite of the sequence domestication process.

Having demonstrated that the endogenous wheat genes Sr22 and Sr33 can provide Pgt resistance in barley and that a sequence-modified version of $\operatorname{Sr} 33\left(\mathrm{Sr} 33^{\alpha}\right)$ maintains function, two additional domesticated wheat $\mathrm{Sr}$ genes were developed. A domesticated Sr 35 construct $\left(\mathrm{Sr} 35^{\alpha}\right)$ was generated by multi-segment Golden Gate assembly which involved removing seven Bpil sequences from the gene (Figure 2d). Three $T_{2}$ families, each derived from an independent $S r 35^{d}$ barley transgenic, were tested with Pgt race TKTTF and each segregated for resistance (Figure $3 e$ and Table S6). A chimeric Sr45 gene construct $\left(S r 45^{d}\right)$ was also assembled by Golden Gate and consisted of a Bsal domesticated Sr45 open reading frame flanked by Sr33 5' and 3' regulatory sequences (Figure 2e). This construct did not require the removal of Bpil sites from Sr33 regulatory sequences, however the assembly resulted in the introduction of four additional nucleotides at both the junction between the Sr33 promoter and start codon of Sr45 and the termination codon of the Sr45 ORF and the Sr33 3' regulatory sequence (Figure 2e). In spite of these modifications four out of eleven $S_{r} 45^{d} \mathrm{~T}_{1}$ families, each derived from an independent primary transgenic line, segregated for Pgt resistance (Figure $\mathbf{3 f}$ and Table S7). For these latter two transgenes their presence in resistant plants and absence in susceptible siblings and control seedlings was again confirmed using hptll and CONSTANS PCR analyses (Figure S1c, S1d, S2c and S2d). These data demonstrate that these wheat NLR genes can be sequence-modified to facilitate further molecular biological manipulation and that regulatory sequences can be functionally exchanged between NLR genes in some instances.

Pathogen and race-specific resistance is maintained by wheat $\mathrm{Sr}$ genes in barley 
To rule out the possibility that these resistant transgenic barley lines are a consequence of an ectopic non-specific defence reaction, we tested these transgenic plants with the barley leaf rust pathogen. All Sr22, Sr33, Sr33 ${ }^{d}, S r 35^{d}$ and $S r 45^{d}$ transgenic barley lines, as well as Golden Promise were susceptible to $P$. hordei. In contrast, a barley control, accession PI531901-4, and the wheat Sr33 line, which is a nonhost of $P$. hordei, were both resistant indicating that the barley resistance observed in stem rust infection assays was specific to Pgt (Figure S3 and Table S8, S9, S10, S11, and S12). Ten $S r 35^{d}$ transgenic $T_{1}$ families were also tested with Pgt race MCCFC (virulent to Sr35) including the three $T_{2}$ lines described above that are resistant to Pgt race TKTTF. All ten $S r 35^{d} T_{1}$ families were susceptible to Pgt race MCCFC (Table S13) indicating that race-specificity of this wheat gene is maintained in transgenic barley.

\section{Discussion}

Barley is a major food staple in the mountainous areas of Central Asia, Southwest Asia, and Northern Africa (Von Bothmer et al., 2003). The re-emergence of wheat stem rust as a major biotic constraint to wheat production also poses a threat to barley production. A recent study revealed very limited resistance to Pgt isolate Ug99 in both cultivated barley and its immediate progenitor $H$. vulgare ssp. spontaneum (Steffenson et al., 2017). This Pgt isolate has caused major epidemics in East Africa since 1999. One avenue for improving resistance to stem rust in barley is to utilise diverse genetic resistance from outside the barley gene pool.

$R$ genes typically function when transferred from one species to another within the same family (Wulff et al., 2011). In this study, the wheat Sr22, Sr33, Sr35, and Sr45 genes were shown to function when transferred to barley and confer race-specific disease resistance to Pgt. Other examples of $R$ gene transfer in monocots include the introduction of the maize NLR gene Rxo1 into rice where it confers resistance to bacterial streak disease (Zhao et al., 2005) and single-cell transient expression assays of the barley Mla6 gene in wheat where it confers AvrMla6-dependent resistance to Blumeria graminis f. sp. hordei (Bgh) (Halterman et al., 2001). In concordance, the wheat Sr22, Sr33, Sr35, and Sr45 genes also function in barley, suggesting that the downstream signalling pathway(s) of NLR proteins in wheat and barley has remained conserved since the divergence of these two species 10 to 14 million years ago (Schlegel, 2013).

The functional transfer of these wheat $S r$ genes into barley potentially provides additional sources of stem rust resistance in this recipient species. Interestingly, in most cases, these barley transformants displayed a highly resistant reaction that is stronger than that observed for the endogenous wheat genes. Similarly, when the barley Rpg1 gene was expressed as a transgene in barley, this also gave rise to a near-immune reaction (Horvath et al., 2003). In contrast to these transgenic barley experiments, near-immune reactions were extremely rare when large scale screening of wild and cultivated barley lines was undertaken using different Pgt races (e.g. Steffenson et al., 2017). The increased resistance conferred by these transgenes may be a consequence of elevated expression arising from position effects or alternatively their interaction with a new genetic background in the case of interspecies transfer. 
Importantly we confirmed that race specificity of the Sr35 gene was maintained in barley. We assume this is also the case for Sr22, Sr33 and Sr45, but cannot confirm this due to an absence of Pgt races virulent on Golden Promise and avirulent to these genes. Unlike most barley cultivars, Golden Promise does show a high level of resistance to many Pgt races which makes Sr gene analysis difficult as it is one of the few transformable barley cultivars available. However, for these latter genes we confirmed that resistance is not a consequence of a non-specific defence reaction caused by ectopic expression of these genes. All transgenic barley lines tested with $P$. hordei, the causal agent of barley leaf rust, were as susceptible as Golden promise control lines demonstrating speciesspecific resistance conferred by these $\mathrm{Sr}$ genes. The phylogenetic relatedness and very similar lifecycle of these two fungal pathogen species argues against a generic defence response being activated. Interestingly these data also suggest that there is little conservation of effectors recognised by these wheat $\mathrm{Srgenes}$ in $P$. hordei.

In the last couple of years, many significant improvements have been made in the field of $R$ gene cloning. For example, sequence comparison of multiple independently-derived mutants, facilitated by various genome complexity reduction technologies, e.g. NLR exome capture (Steuernagel et al., 2016) or chromosome flow sorting (Sánchez-Martín et al., 2016, Thind et al., 2017) was used to rapidly clone Sr22, Sr45, Pm2 and Lr22a from hexaploid wheat. Recently, the requirement of mutagenesis was overcome by combining association genetics with NLR exome capture on a diversity panel of Ae. tauschii (Arora et al., 2018). The resulting application, AgRenSeq, allowed the rapid cloning of Sr46 and SrTA1662 (Arora et al., 2018). These advances coupled with the recent availability of a wheat reference genome will greatly accelerate $R$ gene discovery and cloning.

As more wheat $R$ genes are cloned, they can be tested in barley using the strategy demonstrated in this paper and, in the case of stem rust potentially provide greater control of stem rust disease in this species. The ability to modify these $R$ gene sequences by multi-segment Golden Gate assembly (Weber et al., 2011), even including regulatory elements, and yet maintain gene function will greatly facilitate the manipulation and validation of these genes. Unlike hexaploid wheat, the diploid nature of barley will help understand the fundamental aspects of wheat stem rust resistance. Its greater amenability to mutagenesis will enable the identification of additional genes required for rust $R$ gene function, as well as potential host susceptibility genes. Interestingly a higher proportion of rust $R$ genes in barley are recessive (26.3\%) compared to wheat (6.7\%) (Uauy et al., 2017) and the cloning of recessive resistance genes may provide novel fundamental insight into plant pathogen interactions.

NLR genes are not the sole means of generating disease resistant plants. Another approach to improve wheat stem rust resistance in barley is to combine multiple, additive minor effect quantitative trait loci (QTLS). Bi-parental and genome-wide association studies (GWAS) have identified QTLS associated with stem rust resistance in barley (Mamo, 2013; Sallam et al., 2017; Turuspekov et al., 2016; Zhou et al., 2014; Case et al., 2018). More recently, GWAS on adult plants identified seven novel QTLs conferring adult plant resistance to Pgt race QCCJB and a mixed inoculum of races TTKSK, TTKST, TTKTK and TTKTT, which are all members of the Ug99 group (Case et al., 2017). 
The presence of APR genes or minor effect QTLs has been shown to enhance the strength of racespecific $R$ genes (Hiebert et al., 2016) and promote their longevity (Brun et al., 2010).

Interestingly an APR gene has also been transferred between monocot species by transgenesis and shown to function. The wheat Lr34 adult plant resistance gene (APR), which encodes an ABC transporter, has been shown to provide resistance against multiple, diverse rust, mildew and blast fungal pathogens in barley, rice, durum wheat, maize and sorghum (Risk et al., 2013; Krattinger et al., 2016; Rinaldo et al., 2017; Sucher et al., 2017; Schnippenkoetter et al., 2017), although the mechanism of this resistance is as yet unknown. Wide interspecies transfer of functional disease resistance is therefore not limited to NLR genes.

Given that wheat $R$ genes function in barley, it is reasonable to expect that barley $R$ genes will also function in wheat. Therefore, barley $R$ genes conferring resistance to wheat stripe rust $(P$. strifformis $\mathrm{f}$. sp. triticl) (Dawson et al., 2016) might be deployed in wheat to control this disease. However, caution should be taken so that $R$ genes transferred from one crop to another are not easily overcome which would potentially facilitate a host jump and create a new disease problem. Ideally, $R$ genes with different specificities should be combined as a multi $R$ gene stack, preferably with the inclusion of APR genes (Figure 1c). This is likely to confer more durable resistance by delaying the emergence of resistance-breaking strains of the pathogen (Dangl et al., 2013; McDonald and Linde, 2002).

In summary, functional transfer of the Sr22, Sr33, Sr35 and Sr45 genes into barley has created a new source of resistance to stem rust in barley. As more novel rust $R$ genes are cloned and shown to function in barley, these could subsequently be deployed in a stack to provide broad-spectrum resistance and reduce the risk of resistance breakdown. Future GM field experiments with barley plants expressing single or multiple $S r$ transgenes will be useful to assess the agronomic value of wheat $\mathrm{Srgenes}$ in barley cultivation.

\section{Experimental procedures}

\section{Generation of binary constructs carrying Sr genes}

To assemble a plant transformation construct containing an Sr22 expression cassette, a 9,855 bp fragment of DNA containing the Sr22 coding sequence, 2,377 bp of 5' regulatory sequence (i.e. 5' of the predicted start codon) and 1,560 bp of 3 ' regulatory sequence (i.e. 3 ' of the STOP codon) was synthesised by a commercial DNA synthesis provider (Life Technologies Ltd) with flanking Notl sites. The synthetic DNA was cloned into the Notl site of the pVec8 binary vector (Wang et al., 1998).

The Sr33 gene sequence from the binary vector pVecNeo+Sr33 (Periyannan et al. 2013) was introduced into the binary vector pWBvec8 (Steuernagel et al. 2016) using PspOMI and Notl restriction enzymes. The Sr33 gene sequence in the later construct pWBvec8+Sr33 was proof read using AtM5F1, AtM5R1, AtM5F2, AtM5R2, AtM5F3 and AtM5R3 primers (Periyannan et al. 2013).

To generate $S r 33^{d}$, a 7,854 bp fragment of Sr33, including 2,381 bp of $5^{\prime}$ and 1,405 bp of $3^{\prime}$ regulatory sequence and an 8,255 bp fragment of $S r 35^{d}$, including 2,462 bp of $5^{\prime}$ and 2,615 bp of $3^{\prime}$ regulatory sequence was synthesised flanked by a pair of divergent Bpil recognition sites. Prior to synthesis, any 
recognition sequences for the restriction endonucleases Bsal and Bpil were removed by introducing synonymous mutations in coding sequences and avoiding intron splice junctions. This fragment was simultaneously assembled using Golden Gate cloning (Weber et al., 2011) into a level two Golden Gate acceptor plasmid, pAGM4723 (Weber et al., 2011), with a hygromycin selectable marker cassette to confer resistance to hygromycin.

A transformation construct for barley containing an $S r 45^{d}$ expression cassette was constructed as described in Arora et al., (2018) and the assembled gene cassette was cloned into the Notl site of the pVec8 binary vector. All binary plasmids containing the desired insert were transformed into Agrobacterium tumefaciens (strain AGL1) for transformation of barley.

\section{Barley transformation}

Agrobacterium-mediated transformation of $\mathrm{Sr}$ gene constructs Sr22, $\mathrm{Sr} 33^{d}, \mathrm{Sr} 35^{d}$ and $\mathrm{Sr} 45^{d}$ into barley cv. Golden Promise was performed as described in Harwood (2014). Ten to 12 independent primary transgenic $\left(T_{1}\right)$ plants carrying the $S r$ gene construct were recovered. Confirmation that the transformants carried the Sr gene was done by PCR on genomic DNA using gene specific markers (Table S14). The copy number analysis of $\mathrm{Sr} 22, \mathrm{Sr} 33^{d}, \mathrm{Sr} 35^{d}$, and $\mathrm{Sr} 45^{d}$ by Q-PCR was outsourced to iDNA Genetics, Norwich Research Park, UK. Plants with a single copy transgene were selected and propagated for phenotyping. Binary vector pWBvec8+Sr33 was transformed into cv. Golden Promise using Agrobacterium-mediated transformation as described in Moore et al. (2015). Four advanced generation lines, $\mathrm{SH} 1, \mathrm{SH} 2, \mathrm{SH} 3$ and $\mathrm{SH} 4$, were selected as homozygous for the $\mathrm{Sr} 33$ transgene by screening with $\mathrm{Sr} 33$ sequence-specific primers.

\section{Functional testing of Sr33 and Sr45 with Pgt race MCCFC}

To identify a Pgt race which would be virulent on Golden Promise and avirulent on Sr33 and Sr45, we interrogated a panel of 151 Ae. tauschii accessions which had their NLR repertoires sequenced (Arora et al., 2018) by BLAST search with the Sr33, Sr45, Sr46 and SrTA1662 gene sequences (using a $\geq 99 \%$ identity and $100 \%$ query coverage cut-off). We identified one accession that appeared to contain only Sr33, and four accessions that appeared to contain only Sr45. These accessions were resistant to Pgt race MCCFC, a race which was previously shown to be virulent on Golden Promise (Arora et al., 2013; Kleinhofs et al., 2009), whereas 31 Ae. tauschii accessions which did not appear to contain any of the aforementioned $\mathrm{Sr}$ genes were predominantly susceptible or intermediate in their response to MCCFC (Table S15). From this we concluded that MCCFC is avirulent towards Sr33 and Sr45.

\section{Wheat rust inoculations and phenotypic evaluations}

For the stem rust inoculations, $S r$ barley $\left(S r 22, S r 33^{d}, S r 35^{d}, S r 45^{d}\right) T_{1}$ or $T_{2}$ plants alongside with the susceptible control cv. Golden Promise were infected with Pgt race MCCFC or/and TKTTF 10 days after planting. The inoculated plants were rated for disease response 12-14 days after inoculation as previously described in Yu et al., (2017). For Sr33, $\mathrm{T}_{2}$ plants alongside with the susceptible control cv. Golden Promise were infected with Pgt race MCCFC (isolate 59KS19) and TKTTF (isolate 13ETH181) and the inoculation, incubation and disease assessment procedures were performed as described 
previously (Zhang et al., 2017). At least 10 plants from each homozygous family were evaluted for Sr33 and infection types were recorded once, 12 days after inoculation.

For the leaf rust experiment, each cone rack (98 cones, three seeds per cone, so in total 294 plants per cone rack) received $1 \mathrm{ml}$ of inoculum (15 $\mathrm{mg}$ spore) of $P$. hordei race 4 (Levine and Cherewick, 1952) across the primary leaves of 8-9 day-old seedlings. $P$. hordei isolate 12 TX15-2 was used to inoculate the Sr33-transformed lines. Therefore, each plant received $0.05 \mathrm{mg}$ of urediniospores. To minimize risk of phytotoxicity, the Soltrol 170 oil carrier was evaporated from the leaf surfaces by two hours of gentle fanning under 400 -watt HPS light bulbs. Inoculated seedlings were incubated at $22{ }^{\circ} \mathrm{C}$ inside mist chambers with a $100 \%$ relative air humidity provided by a household ultrasonic humidifier. Post inoculation, plants were moved to a greenhouse running a 16-hour day length with a night temperature of $15^{\circ} \mathrm{C}$ and a day temperature of $20^{\circ} \mathrm{C}$. The information of the resistant control used in the barley leaf rust infection assays, PI531901-4 can be accessed via this link: https://npgsweb.arsgrin.gov/gringlobal/accessiondetail.aspx?id=1426837.

Disease phenotypes (i.e. infection types (ITs) were scored twice for each experiment: first at 10 and then at 12 days post inoculation (dpi) as previously described in Park et al., (2017).

\section{PCR primers and amplification}

PCR assay was performed to confirm the presence of the transgene in transgenic plants or the ability to PCR-amplify the control, the endogenous CONSTANS gene. Specific PCR primers for each (trans)gene were designed using the web-based application Primer3 (http://primer3.ut.ee/) (Table S14). PCRs with a final volume of $20 \mu \mathrm{l}$ contained $10 \mathrm{ng}$ of genomic DNA, $10 \mu \mathrm{l}$ of REDTaq ReadyMix PCR Reaction Mix (Sigma-Aldrich, St Louis, MO, USA) and $10 \mu \mathrm{M}$ of each primer. The reaction schedule for each transgene was; Neomycin phosphotransferase II (nptll) gene $94{ }^{\circ} \mathrm{C}$ for 5 min, 35 cycles of $94^{\circ} \mathrm{C}$ for $30 \mathrm{~s}, 60^{\circ} \mathrm{C}$ for $40 \mathrm{~s}$ and $72{ }^{\circ} \mathrm{C}$ for $70 \mathrm{~s}, 72{ }^{\circ} \mathrm{C}$ for 10 min and $16{ }^{\circ} \mathrm{C}$; Hygromycin phosphotransferase II (hptll) gene $95^{\circ} \mathrm{C}$ for $5 \mathrm{~min}, 29$ cycles of $94^{\circ} \mathrm{C}$ for $30 \mathrm{~s}, 54^{\circ} \mathrm{C}$ for $30 \mathrm{~s}$ and 72 ${ }^{\circ} \mathrm{C}$ for $30 \mathrm{~s}$, and $16^{\circ} \mathrm{C}$; Sr22 and Sr 45 genes $95^{\circ} \mathrm{C}$ for $5 \mathrm{~min}, 29$ cycles of $94^{\circ} \mathrm{C}$ for $30 \mathrm{~s}, 59^{\circ} \mathrm{C}$ for 30 $\mathrm{s}$ and $72{ }^{\circ} \mathrm{C}$ for $30 \mathrm{~s}$, and $16{ }^{\circ} \mathrm{C}$. The reaction schedule for the CONSTANS gene was; $95{ }^{\circ} \mathrm{C}$ for 5 min, 33 cycles of $94^{\circ} \mathrm{C}$ for $30 \mathrm{~s}, 57^{\circ} \mathrm{C}$ for $30 \mathrm{~s}$ and $72{ }^{\circ} \mathrm{C}$ for $30 \mathrm{~s}$, and $16^{\circ} \mathrm{C}$.

\section{Acknowledgements}

The authors wish to thank the support of the Two Blades Foundation, USA, the Lieberman-Okinow Endowment at the University of Minnesota, the USDA-ARS, and the Biotechnology and Biological Sciences Research Council, UK, Grant numbers BB/H019820/1, BB/L009293/1 and BB/L011794/1. MAMdH was supported by a fellowship from Universiti Putra Malaysia (UPM), Malaysia. The authors declare no conflict of interest.

\section{Author contributions}

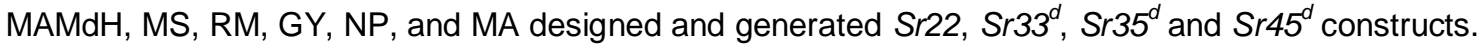
MAMdH, MA and WH performed Sr22, $S r 33^{d}, S r 35^{d}$ and $S r 45^{d}$ transformation. RJ, OM, MR and BJS phenotyped Sr22, Sr33 ${ }^{d}, S r 35^{d}$ and $S r 45^{d}$ transgenics. SC, DB, XX, TR, RM and MA generated the 
Sr33 construct, performed transformation and selected homozygous lines while MNR phenotyped the transgenics. SA and BS performed Ae. tauschii sequence analysis. BBHW, SKP, BJS, EL, NP and WH conceived and designed study. MAMdH drafted manuscript with input from BBHW, BJS, MA, SP and NP. All authors read and approved the final manuscript.

\section{References}

Ade, J., DeYoung, B.J., Golstein, C. and Innes, R.W. (2007) Indirect activation of a plant nucleotide binding site-leucine-rich repeat protein by a bacterial protease. Proceedings of the National Academy of Sciences of the United States of America 104, 2531-2536.

Arora, D., Gross, T. and Brueggeman, R. (2013) Allele characterization of genes required for rpg4mediated wheat stem rust resistance identifies Rpg5 as the $R$ gene. Phytopathology 103, 1153-1161.

Arora, S., Steuernagel, B., Chandramohan, S., Long, Y., Matny, O., Johnson, R., Enk, J., Periyannan, S., Hatta, M.A.M., Athiyannan, N., Cheema, J., Yu, G., Kangara, N., Ghosh, S., Szabo, L.J., Poland, J., Bariana, H., Jones, J.D.G., Bentley, A.R., Ayliffe, M., Olson, E., Xu, S.S., Steffenson, B.J., Lagudah, E. and Wulff, B.B.H. (2018) Resistance gene discovery and cloning by sequence capture and association genetics. bioRxiv.

Ayliffe, M., Singh, R. and Lagudah, E. (2008) Durable resistance to wheat stem rust needed. Current Opinion in Plant Biology 11, 187-192.

Baggs, E., Dagdas, G. and Krasileva, K.V. (2017) NLR diversity, helpers and integrated domains: making sense of the NLR IDentity. Current Opinion in Plant Biology 38, 59-67.

Bhattacharya, S. (2017) Deadly new wheat disease threatens Europe's crops. Nature 542, 145-146.

Brueggeman, R., Druka, A., Nirmala, J., Cavileer, T., Drader, T., Rostoks, N., Mirlohi, A., Bennypaul, H., Gill, U., Kudrna, D., Whitelaw, C., Kilian, A., Han, F., Sun, Y., Gill, K., Steffenson, B. and Kleinhofs, A. (2008) The stem rust resistance gene Rpg5 encodes a protein with nucleotidebinding-site, leucine-rich, and protein kinase domains. Proceedings of the National Academy of Sciences of the United States of America 105, 14970-14975.

Brueggeman, R., Rostoks, N., Kudrna, D., Kilian, A., Han, F., Chen, J., Druka, A., Steffenson, B. and Kleinhofs, A. (2002) The barley stem rust-resistance gene Rpg1 is a novel disease-resistance gene with homology to receptor kinases. Proceedings of the National Academy of Sciences 99, 9328-9333.

Brun, H., Chevre, A.M., Fitt, B.D., Powers, S., Besnard, A.L., Ermel, M., Huteau, V., Marquer, B., Eber, F., Renard, M. and Andrivon, D. (2010) Quantitative resistance increases the durability of qualitative resistance to Leptosphaeria maculans in Brassica napus. The New Phytologist 185, 285-299.

Case, A. J., Bhavani, S., Macharia, G., Pretorius, Z. A., Coetzee, V., Kloppers, F. J., Tyagi, P., Gina Brown-Guedira, G., and Steffenson, B. J. 2018. Mapping adult plant stem rust resistance in barley accessions Hietpas-5 and GAW-79. Theoretical and Applied Genetics (accepted).

Case, A.J., Bhavani, S., Macharia, G. and Steffenson, B.J. (2017) Genome-wide association study of stem rust resistance in a world collection of cultivated barley. Theoretical and Applied Genetics 131, 107-126.

Chen, S., Zhang, W., Bolus, S., Rouse, M. N., and Dubcovsky, J. 2018. Identification and characterization of wheat stem rust resistance gene Sr21 effective against the Ug99 race group at high temperature. PLoS Genetics 14, e1007287.

Chung, E.H., da Cunha, L., Wu, A.J., Gao, Z., Cherkis, K., Afzal, A.J., Mackey, D. and Dangl, J.L. (2011) Specific threonine phosphorylation of a host target by two unrelated type III effectors activates a host innate immune receptor in plants. Cell Host \& Microbe 9, 125-136.

Dangl, J.L., Horvath, D.M. and Staskawicz, B.J. (2013) Pivoting the plant immune system from dissection to deployment. Science (New York, N.Y.) 341, 746-751.

Dawson, A.M., Ferguson, J.N., Gardiner, M., Green, P., Hubbard, A. and Moscou, M.J. (2016) Isolation and fine mapping of Rps6: an intermediate host resistance gene in barley to wheat stripe rust. Theoretical and Applied Genetics 129, 831-843.

Day, B., Dahlbeck, D., Huang, J., Chisholm, S.T., Li, D. and Staskawicz, B.J. (2005) Molecular basis for the RIN4 negative regulation of RPS2 disease resistance. Plant Cell 17, 1292-1305.

De Wolf, E., Murray, T., Paul, P., Osborne, L. and Tenuta, A. (2011) Identification and management of stem rust on wheat and barley. USDA-CREES Extension IPM 2009-41533-05331.

Dill-Macky, R., Rees, R. and Platz, G. (1991) Inoculum pressure and the development of stem rust epidemics in barley. Australian Journal of Agricultural Research 42, 769-777. 
Dodds, P.N., Lawrence, G.J., Catanzariti, A.-M., Ayliffe, M.A. and Ellis, J.G. (2004) The Melampsora lini AvrL567 avirulence genes are expressed in haustoria and their products are recognized inside plant cells. The Plant Cell 16, 755-768.

Dodds, P.N. and Rathjen, J.P. (2010) Plant immunity: towards an integrated view of plant-pathogen interactions. Nature Reviews. Genetics 11, 539-548.

Ellis, J.G., Lagudah, E.S., Spielmeyer, W. and Dodds, P.N. (2014) The past, present and future of breeding rust resistant wheat. Frontiers in Plant Science 5, 641.

Engler, C., Kandzia, R. and Marillonnet, S. (2008) A one pot, one step, precision cloning method with high throughput capability. PloS One 3, e3647.

Erickson, A.W. (1945) McFadden's Hope: Fighting Plant Breeders Win Battle for Bread. Minneapolis, MN:Field Notes Crop Reporting Service.

Fetch, T., Johnston, P.A. and Pickering, R. (2009) Chromosomal location and inheritance of stem rust resistance transferred from Hordeum bulbosum into cultivated barley ( $H$. vulgare). Phytopathology 99, 339-343.

Halterman, D., Zhou, F., Wei, F., Wise, R.P. and Schulze-Lefert, P. (2001) The MLA6 coiled-coil, NBS-LRR protein confers AvrMla6-dependent resistance specificity to Blumeria graminis f. sp. hordei in barley and wheat. The Plant Journal : For Cell and Molecular Biology 25, 335348.

Harwood, W.A. (2014) A protocol for high-throughput Agrobacterium-mediated barley transformation. In: Cereal Genomics: Methods and Protocols (Henry, R.J. and Furtado, A. eds), pp. 251-260. Totowa, NJ: Humana Press.

Hiebert, C.W., Kolmer, J.A., McCartney, C.A., Briggs, J., Fetch, T., Bariana, H., Choulet, F., Rouse, M.N. and Spielmeyer, W. (2016) Major gene for field stem rust resistance co-locates with resistance gene Sr12 in 'Thatcher' wheat. PloS one 11, e0157029.

Horvath, H., Rostoks, N., Brueggeman, R., Steffenson, B., von Wettstein, D. and Kleinhofs, A. (2003) Genetically engineered stem rust resistance in barley using the Rpg1 gene. Proceedings of the National Academy of Sciences of the United States of America 100, 364-369.

Jedel, P.E. (1990) A gene for resistance to Puccinia graminis f. sp. tritici in PI 382313. Barley Genet Newsl. 20, 43-44.

Jedel, P.E., Metcalfe, D.R. and Martens, J.W. (1989) Assessment of barley accessions PI 382313, PI 382474, PI 382915, and PI 382976 for stem rust resistance. Crop Science 29, 1473-1477.

Jin, Y., Steffenson, B.J. and Miller, J.D. (1994) Inheritance of resistance to pathotypes QCC and MCC of Puccinia graminis f. sp. tritici in barley line Q21861 and temperature effects on the expression of resistance. Phytopathology 84, 452-455.

Jin, Y., Szabo, L.J., Pretorius, Z.A., Singh, R.P., Ward, R. and Fetch, T. (2008) Detection of virulence to resistance gene Sr24 within race TTKS of Puccinia graminis f. sp. tritici. Plant Disease 92, 923-926.

Kawashima, C.G., Guimaraes, G.A., Nogueira, S.R., MacLean, D., Cook, D.R., Steuernagel, B., Baek, J., Bouyioukos, C., Melo Bdo, V., Tristao, G., de Oliveira, J.C., Rauscher, G., Mittal, S., Panichelli, L., Bacot, K., Johnson, E., Iyer, G., Tabor, G., Wulff, B.B., Ward, E., Rairdan, G.J., Broglie, K.E., Wu, G., van Esse, H.P., Jones, J.D. and Brommonschenkel, S.H. (2016) A pigeonpea gene confers resistance to Asian soybean rust in soybean. Nature Biotechnology 34, 661-665.

Kleinhofs, A., Brueggeman, R., Nirmala, J., Zhang, L., Mirlohi, A., Druka, A., Rostoks, N. and Steffenson, B.J. (2009) Barley stem rust resistance genes: structure and function. The Plant Genome 2, 109-120.

Knott, D.R. (1984) The genetic nature of mutations of a gene for yellow pigment linked to Lr19 in 'Agatha' wheat. Canadian Journal of Genetics and Cytology 26, 392-393.

Kourelis, J. and van der Hoorn, R.A.L. (2018) Defended to the nines: 25 years of resistance gene cloning identifies nine mechanisms for $R$ protein function. The Plant Cell. http://www.plantcell.org/content/early/2018/01/30/tpc.17.00579

Krattinger, S.G., Sucher, J., Selter, L.L., Chauhan, H., Zhou, B., Tang, M., Upadhyaya, N.M., Mieulet, D., Guiderdoni, E., Weidenbach, D., Schaffrath, U., Lagudah, E.S. and Keller, B. (2016) The wheat durable, multipathogen resistance gene Lr34 confers partial blast resistance in rice. Plant Biotechnology Journal 14, 1261-1268.

Levine, M.N. and Cherewick, W.J. (1952) Studies on Dwarf Leaf Rust of Barley: U.S. Department of Agriculture.

Mago, R., Bariana, H.S., Dundas, I.S., Spielmeyer, W., Lawrence, G.J., Pryor, A.J. and Ellis, J.G. (2005a) Development of PCR markers for the selection of wheat stem rust resistance genes Sr24 and Sr26 in diverse wheat germplasm. Theoretical and Applied Genetics 111, 496-504. 
Mago, R., Miah, H., Lawrence, G.J., Wellings, C.R., Spielmeyer, W., Bariana, H.S., McIntosh, R.A., Pryor, A.J. and Ellis, J.G. (2005b) High-resolution mapping and mutation analysis separate the rust resistance genes Sr31, Lr26 and Yr9 on the short arm of rye chromosome 1. Theoretical and Applied Genetics. 112, 41-50.

Mago, R., Zhang, P., Vautrin, S., Simkova, H., Bansal, U., Luo, M.C., Rouse, M., Karaoglu, H., Periyannan, S., Kolmer, J., Jin, Y., Ayliffe, M.A., Bariana, H., Park, R.F., McIntosh, R., Dolezel, J., Berges, H., Spielmeyer, W., Lagudah, E.S., Ellis, J.G. and Dodds, P.N. (2015) The wheat Sr50 gene reveals rich diversity at a cereal disease resistance locus. Nature Plants 1, 15186.

Mamo, B.E. (2013) Genetic characterization of multiple disease resistance and agronomical and nutritional traits in Hordeum. In: Department of Plant Pathology. UMI Dissertations Publishing: University of Minnesota.

Marais, G.F. (1992) The modification of a common wheat-Thinopyrum distichum translocated chromosome with a locus homoeoallelic to Lr19. Theoretical and Applied Genetics. 85, 73-78.

McDonald, B.A. and Linde, C. (2002) Pathogen population genetics, evolutionary potential, and durable resistance. Annual Review of Phytopathology 40, 349-379.

McFadden, E.S. (1930) A successful transfer of emmer characters to vulgare wheat. Journal of the American Society of Agronomy 22, 1020-1034.

McIntosh, R., Dubcovsky, J., Rogers, W., Morris, C. and Xia, X. (2017) Catalogue of gene symbols for wheat: 2017 supplement. Komugi Wheat Genet. Resour. Database Comm. Natl. BioResour. Proj., Kyoto, Japan, updated 11. http://shigen.nig.ac.jp/wheat/komugi/genes/symbolClassList.jsp

Mclntosh, R., Wellings, C. and Park, R. (1995) Wheat rusts: an atlas of resistance genes: CSIRO Publishing.

McIntosh, R.A. and Gyarfas, J. (1971) Triticum timopheevi as a source of resistance to wheat stem rust. Zeitschrift für Pflazenzüchtung 66, 240-248.

Moore, J.W., Herrera-Foessel, S., Lan, C., Schnippenkoetter, W., Ayliffe, M., Huerta-Espino, J., Lillemo, M., Viccars, L., Milne, R., Periyannan, S., Kong, X., Spielmeyer, W., Talbot, M., Bariana, H., Patrick, J.W., Dodds, P., Singh, R and Lagudah, E. (2015). A recently evolved hexose transporter variant confers resistance to multiple pathogens in wheat. Nature Genetics 47, 1494-1498

Moseman, J.G. and Roane, C.W. (1959) Physiologic races of barley leaf rust (Puccinia hordei) isolated in the United States from 1956 to 1958. Plant Disease 43, 1000-1003.

Niu, Z., Klindworth, D.L., Yu, G., L Friesen, T., Chao, S., Jin, Y., Cai, X., Ohm, J.-B., Rasmussen, J.B. and Xu, S.S. (2014) Development and characterization of wheat lines carrying stem rust resistance gene Sr43 derived from Thinopyrum ponticum. Theoretical and Applied Genetics 127, 969-980.

Olivera Firpo, P.D., Newcomb, M., Flath, K., Sommerfeldt-Impe, N., Szabo, L.J., Carter, M., Luster, D.G. and Jin, Y. (2017) Characterization of Puccinia graminis f. sp. tritici isolates derived from an unusual wheat stem rust outbreak in Germany in 2013. Plant Pathology 66, 1258-1266.

Olivera, P., Newcomb, M., Szabo, L.J., Rouse, M., Johnson, J., Gale, S., Luster, D.G., Hodson, D., Cox, J.A., Burgin, L., Hort, M., Gilligan, C.A., Patpour, M., Justesen, A.F., Hovmoller, M.S., Woldeab, G., Hailu, E., Hundie, B., Tadesse, K., Pumphrey, M., Singh, R.P. and Jin, Y. (2015) Phenotypic and genotypic characterization of race TKTTF of Puccinia graminis f. sp. tritici that caused a wheat stem rust epidemic in Southern Ethiopia in 2013-14. Phytopathology 105, 917-928.

Park, R.F., Golegaonkar, P.G., Derevnina, L., Sandhu, K.S., Karaoglu, H., Elmansour, H.M., Dracatos, P.M. and Singh, D. (2015) Leaf rust of cultivated barley: pathology and control. Annual Review of Phytopathology 53, 565-589.

Patterson, F.L., Shands, R.G. and Dickson, J.G. (1957) Temperature and seasonal effects on seedling reactions of barley varieties to three races of Puccinia graminis f. $\mathrm{sp}$. tritici. Phytopathology 47, 395-402.

Periyannan, S., Moore, J., Ayliffe, M., Bansal, U., Wang, X., Huang, L., Deal, K., Luo, M., Kong, X., Bariana, H., Mago, R., McIntosh, R., Dodds, P., Dvorak, J. and Lagudah, E. (2013) The gene Sr33, an ortholog of barley Mla genes, encodes resistance to wheat stem rust race Ug99. Science 341, 786-788.

Powers, L. and Hines, L. (1933) Inheritance of reaction to stem rust and barbing awns in barley crosses. Journal of Agricultural Research. 46, 1121-1129. 
Pretorius, Z.A., Singh, R.P., Wagoire, W.W. and Payne, T.S. (2000) Detection of virulence to wheat stem rust resistance gene Sr31 in Puccinia graminis f. sp. tritici in Uganda. Plant Disease 84, 203-203.

Rinaldo, A., Gilbert, B., Boni, R., Krattinger, S.G., Singh, D., Park, R.F., Lagudah, E. and Ayliffe, M. (2017) The Lr34 adult plant rust resistance gene provides seedling resistance in durum wheat without senescence. Plant Biotechnology Journal 15, 894-905.

Risk, J.M., Selter, L.L., Chauhan, H., Krattinger, S.G., Kumlehn, J., Hensel, G., Viccars, L.A., Richardson, T.M., Buesing, G., Troller, A., Lagudah, E.S. and Keller, B. (2013) The wheat Lr34 gene provides resistance against multiple fungal pathogens in barley. Plant Biotechnology Journal 11, 847-854.

Rouse, M.N. and Jin, Y. (2011) Genetics of resistance to race TTKSK of Puccinia graminis f. sp. tritici in Triticum monococcum. Phytopathology 101, 1418-1423.

Saintenac, C., Zhang, W., Salcedo, A., Rouse, M.N., Trick, H.N., Akhunov, E. and Dubcovsky, J. (2013) Identification of wheat gene Sr35 that confers resistance to Ug99 stem rust race group. Science 341, 783-786.

Sallam, A.H., Tyagi, P., Brown-Guedira, G., Muehlbauer, G.J., Hulse, A. and Steffenson, B.J. (2017) Genome-wide association mapping of stem rust resistance in Hordeum vulgare subsp. spontaneum. G3 7, 3491-3507.

Sánchez-Martín, J., Steuernagel, B., Ghosh, S., Herren, G., Hurni, S., Adamski, N., Vrána, J., Kubaláková, M., Krattinger, S.G., Wicker, T., Doležel, J., Keller, B. and Wulff, B.B.H. (2016) Rapid gene isolation in barley and wheat by mutant chromosome sequencing. Genome Biology 17, 221.

Schlegel, R.H.J. (2013) Rye: Genetics, Breeding, and Cultivation:CRC Press.

Schnippenkoetter, W., Lo, C., Liu, G., Dibley, K., Chan, W.L., White, J., Milne, R., Zwart, A., Kwong, E., Keller, B., Godwin, I., Krattinger, S.G. and Lagudah, E. (2017) The wheat Lr34 multipathogen resistance gene confers resistance to anthracnose and rust in sorghum. Plant Biotechnology Journal 15, 1387-1396.

Shamanin, V., Salina, E., Wanyera, R., Zelenskiy, Y., Olivera, P. and Morgounov, A. (2016) Genetic diversity of spring wheat from Kazakhstan and Russia for resistance to stem rust Ug99. Euphytica 212, 287-296.

Singh, R.P., Hodson, D.P., Huerta-Espino, J., Yue Jin; Njau, P., Wanyera, R., Herrera-Foessel, S.A. and Ward, R.W. (2008) Will stem rust destroy the world's wheat crop? Advances in Agronomy 98, 271-309.

Singh, R.P., Hodson, D.P., Jin, Y., Huerta-Espino, J., Kinyua, M.G., Wanyera, R., Njau, P. and Ward, R.W. (2006) Current status, likely migration and strategies to mitigate the threat to wheat production from race Ug99 (TTKS) of stem rust pathogen. CAB Reviews: Perspectives in Agriculture, Veterinary Science, Nutrition and Natural Resources 1.

Stakman, E.C. (1957) Problems in preventing plant disease epidemics. American Journal of Botany 44, 259-267.

Stakman, E.C., Stewart, D.M. and Loegering, W.Q. (1962) Identification of physiologic races of Puccinia graminis var. tritici:United States Department of Agriculture, Agricultural Research Service.

Steffenson, B.J. (1992) Analysis of durable resistance to stem rust in barley. Euphytica 63, 153-167.

Steffenson, B.J., Case, A.J., Pretorius, Z.A., Coetzee, V., Kloppers, F.J., Zhou, H., Chai, Y., Wanyera, R., Macharia, G., Bhavani, S. and Grando, S. (2017) Vulnerability of barley to african pathotypes of Puccinia graminis f. sp. tritici and sources of resistance. Phytopathology 107, 950-962.

Steffenson, B.J., Jin, Y., Brueggeman, R.S., Kleinhofs, A. and Sun, Y. (2009) Resistance to stem rust race TTKSK maps to the rpg4/Rpg5 complex of chromosome $5 \mathrm{H}$ of barley. Phytopathology 99, 1135-1141.

Steffenson, B.J., Wilcoxson, R.D. and Roelfs, A.P. (1984) Inheritance of resistance to Puccinia graminis f. sp. secalis in barley. Plant Disease 68, 762-763.

Steuernagel, B., Periyannan, S.K., Hernandez-Pinzon, I., Witek, K., Rouse, M.N., Yu, G., Hatta, A., Ayliffe, M., Bariana, H., Jones, J.D., Lagudah, E.S. and Wulff, B.B. (2016) Rapid cloning of disease-resistance genes in plants using mutagenesis and sequence capture. Nature Biotechnology 34, 652-655.

Sucher, J., Boni, R., Yang, P., Rogowsky, P., Buchner, H., Kastner, C., Kumlehn, J., Krattinger, S.G. and Keller, B. (2017) The durable wheat disease resistance gene Lr34 confers common rust and northern corn leaf blight resistance in maize. Plant Biotechnology Journal 15, 489-496. 
Sun, Y. and Steffenson, B.J. (2005) Reaction of barley seedlings with different stem rust resistance genes to Puccinia graminis f. sp. tritici and Puccinia graminis f. sp. secalis. Canadian Journal of Plant Pathology 27, 80-89.

Sun, Y., Steffenson, B.J. and Jin, Y. (1996) Genetics of resistance to Puccinia graminis f. sp. secalis in barley line Q21861. Phytopathology 86, 1299-1302.

Tai, T.H., Dahlbeck, D., Clark, E.T., Gajiwala, P., Pasion, R., Whalen, M.C., Stall, R.E. and Staskawicz, B.J. (1999) Expression of the Bs2 pepper gene confers resistance to bacterial spot disease in tomato. Proceedings of the National Academy of Sciences 96, 14153-14158.

Thind, A.K., Wicker, T., Simkova, H., Fossati, D., Moullet, O., Brabant, C., Vrana, J., Dolezel, J. and Krattinger, S.G. (2017) Rapid cloning of genes in hexaploid wheat using cultivar-specific longrange chromosome assembly. Nature Biotechnology 35, 793-796.

Turuspekov, Y., Ormanbekova, D., Rsaliev, A. and Abugalieva, S. (2016) Genome-wide association study on stem rust resistance in Kazakh spring barley lines. BMC Plant Biology 16 Suppl 1, 6.

Uauy, C., Wulff, B.B.H. and Dubcovsky, J. (2017) Combining traditional mutagenesis with new highthroughput sequencing and genome editing to reveal hidden variation in polyploid wheat. Annual Review of Genetics 51, 435-454.

Von Bothmer, R., van Hintum, T.J.L., Knüpffer, H. and Sato, K. (2003) Diversity in barley (Hordeum vulgare). Amsterdam, the Netherlands:Elsevier B. V.

Wang, M., Li, Z., Matthews, P.R., Upadhyaya, N.M. and Waterhouse, P.M. (1998) Improved vectors for Agrobacterium tumefaciens-mediated transformation of monocot plants. pp. 401-408. International Society for Horticultural Science (ISHS), Leuven, Belgium.

Waterhouse, W.L. (1927) Studies in the inheritance of resistance to leaf rust, Puccinia anomala Rostr., in crosses of barley.1. Journal and Proceedings of the Royal Society of New South Wales 61, 218-247.

Weber, E., Engler, C., Gruetzner, R., Werner, S. and Marillonnet, S. (2011) A modular cloning system for standardized assembly of multigene constructs. PloS One 6, e16765.

Wulff, B.B., Horvath, D.M. and Ward, E.R. (2011) Improving immunity in crops: new tactics in an old game. Current Opinion in Plant Biology 14, 468-476.

Wulff, B.B. and Moscou, M.J. (2014) Strategies for transferring resistance into wheat: from wide crosses to GM cassettes. Frontiers in Plant Science 5, 692.

Yu, G., Champouret, N., Steuernagel, B., Olivera, P.D., Simmons, J., Williams, C., Johnson, R., Moscou, M.J., Hernandez-Pinzon, I., Green, P., Sela, H., Millet, E., Jones, J.D.G., Ward, E.R., Steffenson, B.J. and Wulff, B.B.H. (2017) Discovery and characterization of two new stem rust resistance genes in Aegilops sharonensis. Theoretical and Applied Genetics. 130, 1207-1222.

Zhang, W., Chen, S., Abate, Z., Nirmala, J., Rouse, M.N. and Dubcovsky, J. (2017) Identification and characterization of $\mathrm{Sr} 13$, a tetraploid wheat gene that confers resistance to the Ug99 stem rust race group. Proceedings of the National Academy of Sciences of the United States of America 114, E9483-e9492.

Zhao, B., Lin, X., Poland, J., Trick, H., Leach, J. and Hulbert, S. (2005) A maize resistance gene functions against bacterial streak disease in rice. Proceedings of the National Academy of Sciences of the United States of America 102, 15383-15388.

Zhou, H., Steffenson, B.J., Muehlbauer, G., Wanyera, R., Njau, P. and Ndeda, S. (2014) Association mapping of stem rust race TTKSK resistance in US barley breeding germplasm. Theoretical and Applied Genetics 127, 1293-1304

\section{Supporting information}

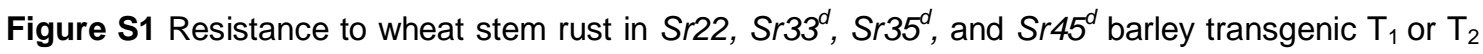
families segregating for the transgene correlates with the presence of the transgene.

Figure S2 Amplification of the barley endogenous CONSTANS gene using genomic DNA of Sr gene transgenics and Golden Promise (positive control) as a template.

Figure S3 Leaf rust infection assays with $P$. hordei race 4 on Sr22, Sr33, Sr33 ${ }^{d}, \operatorname{Sr} 35^{d}$, and $\operatorname{Sr} 45^{d}$ representative $T_{1}$ and $T_{2}$ transgenics at the seedling stage. 
Table S1 List of binary constructs carrying Srgene.

Table S2 Stem rust infection assays with Pgt race MCCFC on Sr22 $\mathrm{T}_{1}$ families.

Table S3 Stem rust infection assays with Pgt race MCCFC on Sr33 $\mathrm{T}_{2}$ homozygous lines.

Table S4 Stem rust infection assays with Pgt race TKTTF on Sr33 $\mathrm{T}_{2}$ homozygous lines.

Table S5 Stem rust infection assays with Pgt race MCCFC on $\mathrm{Sr}_{3}{ }^{d} \mathrm{~T}_{1}$ families.

Table S6 Stem rust infection assays with Pgt race TKTTF on $S r 35^{d} \mathrm{~T}_{2}$ families.

Table S7 Stem rust infection assays with Pgt race MCCFC on Sr45 ${ }^{d} T_{1}$ families.

Table S8 Puccinia hordei race 4 infection assays on Sr22 $\mathrm{T}_{2}$ families.

Table S9 Puccinia hordei race 4 infection assays on $\mathrm{Sr}_{3} 3 \mathrm{~T}_{2}$ homozygous lines.

Table S10 Puccinia hordei race 4 infection assays with on $S r 33^{d} \mathrm{~T}_{2}$ families.

Table S11 Puccinia hordei race 4 infection assays on $S r 35^{d} \mathrm{~T}_{2}$ families.

Table $\mathbf{S} 12$ Puccinia hordei race 4 infection assays on $S r 45^{d} T_{2}$ families.

Table S13 Stem rust infection assays with Pgt race MCCFC on Sr35 $\mathrm{T}_{1}$ families.

Table S14 PCR primers used in this study.

Table S15 Functional testing of Sr33 and Sr45 with Pgt race MCCFC.

\section{Figure legends}

Figure 1: Strategy for improving barley resistance to stem rust with cloned wheat Srgenes. (a) Wheat and barley diverged from a common Triticeae ancestor 10-14 million years ago. (b) Cloned Sr genes from wheat, rye and the domesticated and wild relatives of wheat (coloured circles), function when transformed into barley (black outline, this study). (c) The future stacking of multiple cloned Sr genes in barley may provide durable resistance to wheat stem rust. At, Aegilops tauschii; Td, Triticum turgidum ssp. durum; Tb, Triticum boeoticum; Tm, Triticum monococcum; Sc, Secale cereale.

Figure 2: Schematic overview (not shown to scale) of the constructs described in this study. Binary construct containing $(a, b)$ full-length Sr22 and Sr33, respectively, driven by their 5' and 3 ' native

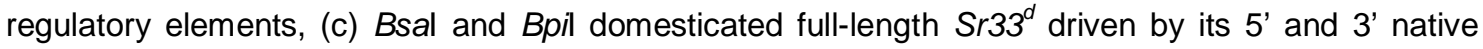
regulatory elements, (d) Bpil domesticated full length $S r 35^{d}$ driven by its $5^{\prime}$ and 3 ' native regulatory elements, and (e) Bsal domesticated Sr45 driven by 5' and 3' Sr33 regulatory elements. The nonnative four-nucleotide linker in pBW_0141 was introduced immediately before the start codon (underlined) and immediately after the stop codon (underlined). Grey arrows correspond to the removed Bpil sites and white arrows correspond to the removed Bsal sites. Blue and green rectangles correspond respectively to hptll and nptll plant selectable marker genes.

Figure 3: Transgenic Sr22, $\mathrm{Sr} 33, \mathrm{Sr} 33^{d}, \mathrm{Sr} 35^{d}$, and $\mathrm{Sr} 45^{d}$ expression provide resistance against stem rust in barley at the seedling stage. Stem rust infection assays using Pgt race (a) MCCFC on Sr22 segregating $T_{1}$ transgenics 1370-11-01 (A-D) and comparison to susceptible cv. Golden Promise wild type used in transformation, (b) MCCFC on Sr33 $\mathrm{T}_{2}$ homozygous transgenics 1-1, 2-1, 3-1, 4-1 and 
comparison to resistant Sr33 wheat and susceptible cv. Golden Promise, (c) TKTTF on Sr33 $\mathrm{T}_{2}$ homozygous transgenics 1-7, 2-2, 3-1, 4-3 and comparison to resistant Sr33 wheat and susceptible cv. Golden Promise, (d) MCCFC on Sr33 ${ }^{d} \mathrm{~T}_{1}$ segregating transgenics 1024-13-01 (A-C) and comparison to resistant Sr33 wheat and the susceptible Sr33 EMS-induced mutant wheat line (E2) and susceptible cv. Golden Promise, (e) TKTTF on $T_{2}$ segregating Sr35 ${ }^{d}$ transgenics 1352-06-01 (A, $B, C, E, F, G$ ), and comparison to susceptible cv. Golden Promise, and (f) MCCFC on $T_{1}$ segregating Sr45 transgenics 1613-04-01 ( $\mathrm{A}$ and $\mathrm{C}$ ), 1613-05-01 (A and B) and comparison to resistant check Q21861 and susceptible cv. Golden Promise. 


\section{Figures}

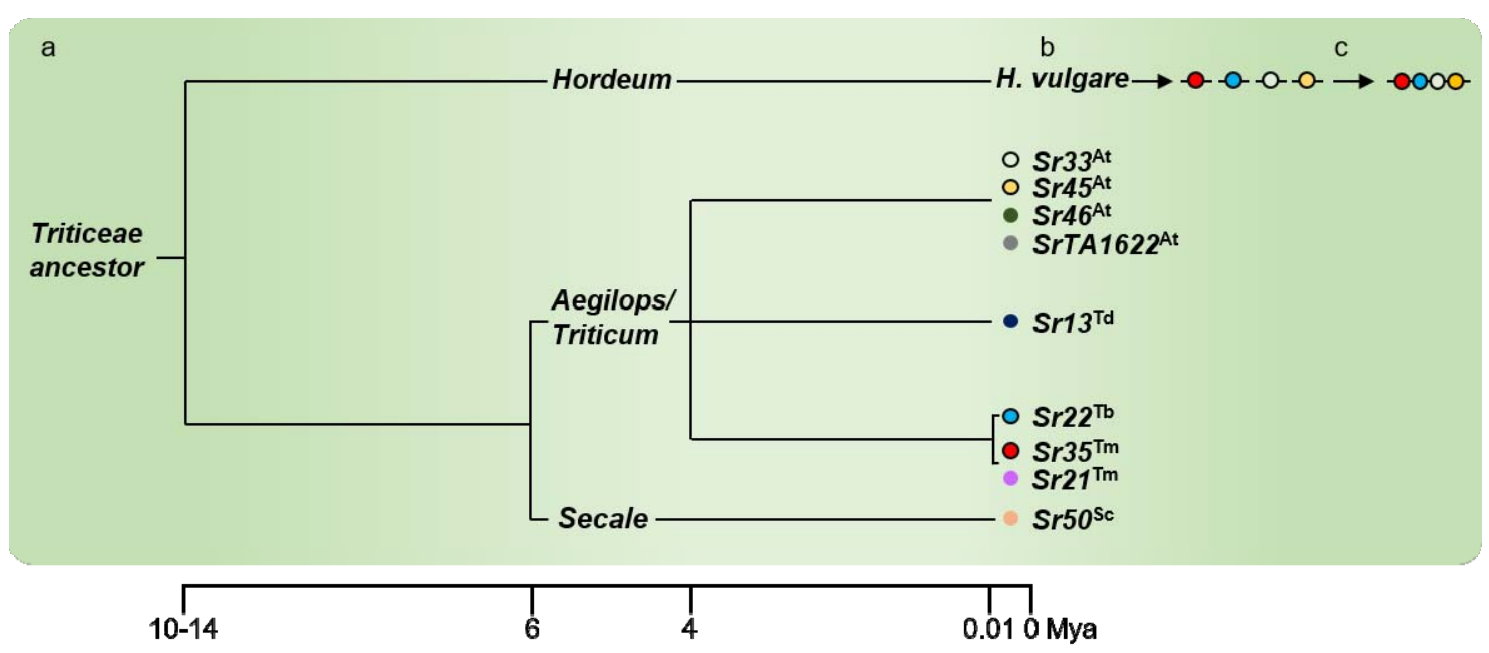

Figure 1 Strategy for improving barley resistance to stem rust with cloned wheat Srgenes. (a) Wheat and barley diverged from a common Triticeae ancestor 10-14 million years ago. (b) Cloned Sr genes from wheat, rye and the domesticated and wild relatives of wheat (coloured circles), function when transformed into barley (black outline, this study). (c) The future stacking of multiple cloned Sr genes in barley may provide durable resistance to wheat stem rust. At, Aegilops tauschii; Td, Triticum turgidum ssp. durum; Tb, Triticum boeoticum; Tm, Triticum monococcum; Sc, Secale cereale.

a)

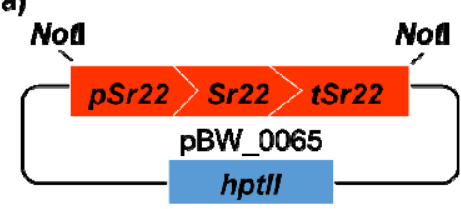

d)

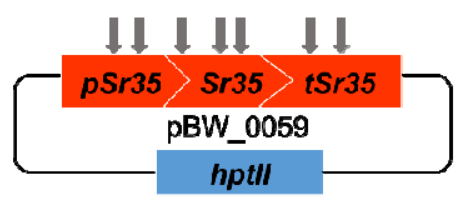

b)

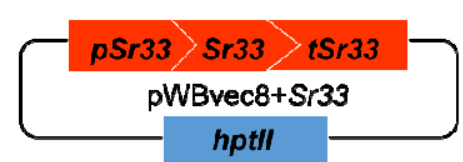

c)

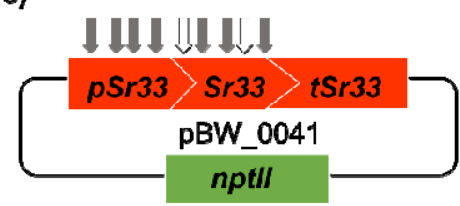

e) AATGATG TAGGCTT

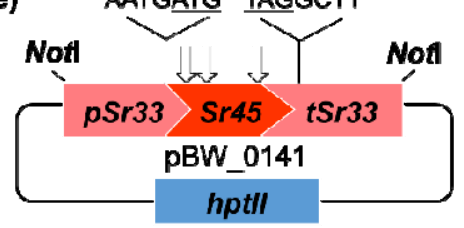

Figure 2 Schematic overview (not shown to scale) of the constructs described in this study. Binary construct containing (a,b) full-length Sr22 and Sr33, respectively, driven by their 5' and 3' native regulatory elements, (c) Bsal and Bpil domesticated full-length $S r 33^{d}$ driven by its 5' and 3' native regulatory elements, (d) Bpil domesticated full length $S r 35^{d}$ driven by its $5^{\prime}$ and 3' native regulatory elements, and (e) Bsal domesticated Sr45 driven by 5' and 3' Sr33 regulatory elements. The nonnative four-nucleotide linker in pBW_0141 was introduced immediately before the start codon (underlined) and immediately after the stop codon (underlined). Grey arrows correspond to the removed Bpil sites and white arrows correspond to the removed Bsal sites. Blue and green rectangles correspond respectively to hptll and nptll plant selectable marker genes. 
(a)

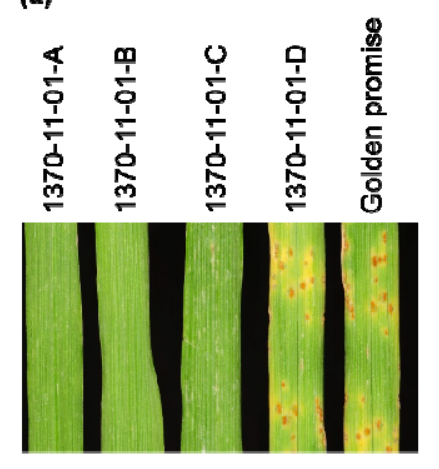

(b)

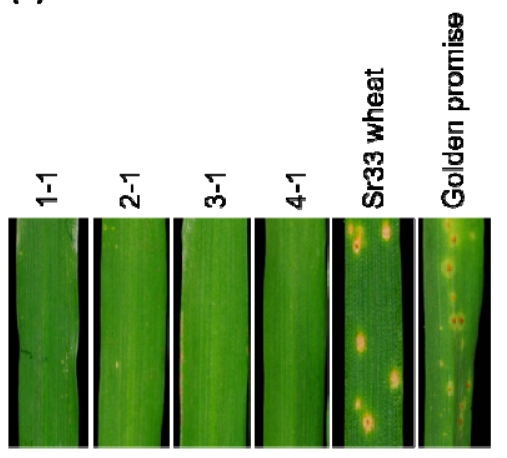

(c)

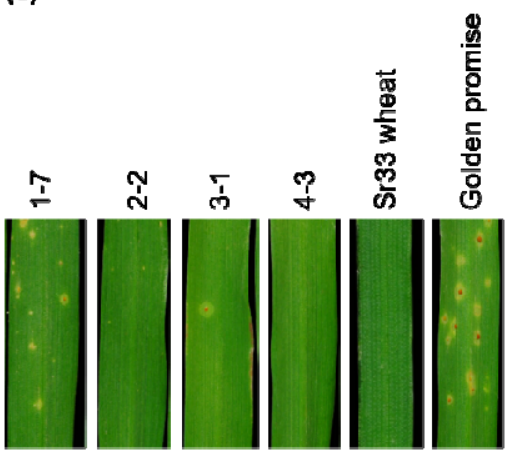

(d)

(e)

(f)

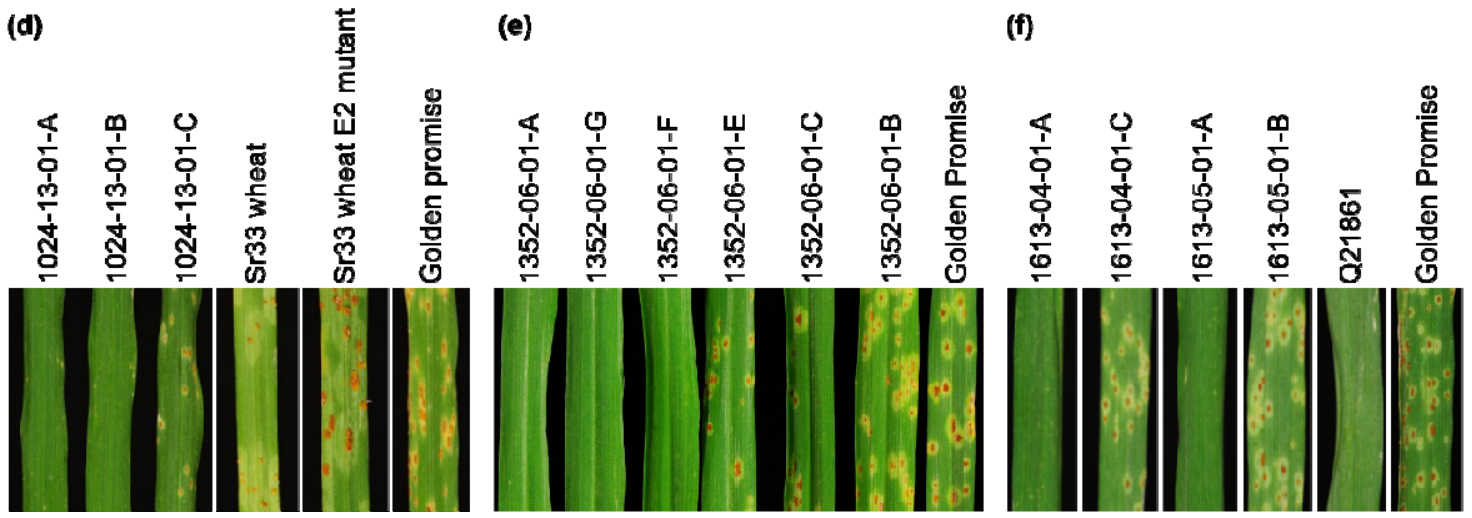

Figure 3 Transgenic Sr22, Sr33, Sr33 ${ }^{d}, S r 35^{d}$, and $S r 45^{d}$ expression provide resistance against stem rust in barley at the seedling stage. Stem rust infection assays using Pgt race (a) MCCFC on Sr22 segregating $T_{1}$ transgenics 1370-11-01 (A-D) and comparison to susceptible cv. Golden Promise wild type used in transformation, (b) MCCFC on Sr33 $\mathrm{T}_{2}$ homozygous transgenics 1-1, 2-1, 3-1, 4-1 and comparison to resistant Sr33 wheat and susceptible cv. Golden Promise, (c) TKTTF on Sr33 $\mathrm{T}_{2}$ homozygous transgenics 1-7, 2-2, 3-1, 4-3 and comparison to resistant Sr33 wheat and susceptible cv. Golden Promise, (d) MCCFC on Sr33 ${ }^{d} \mathrm{~T}_{1}$ segregating transgenics 1024-13-01 (A-C) and comparison to resistant Sr33 wheat and the susceptible Sr33 EMS-induced mutant wheat line (E2) and susceptible cv. Golden Promise, (e) TKTTF on $\mathrm{T}_{2}$ segregating Sr35 transgenics 1352-06-01 (A, $B, C, E, F, G$ ), and comparison to susceptible cv. Golden Promise, and (f) MCCFC on $T_{1}$ segregating Sr45 transgenics 1613-04-01 (A and C), 1613-05-01 (A and B) and comparison to resistant check Q21861 and susceptible cv. Golden Promise. 